\title{
Cytokines and neutrophil extracellular traps in the equine endometrium: friends or foes?
}

\author{
António Galvãol,2, Maria Rosa Rebordão', Anna Z. Szóstek², Dariusz J. Skarzynski² and Graça Ferreira-Dias ${ }^{1}$ \\ C.I.I.S.A., Faculty of Veterinary Medicine, Technical University of Lisbon, Lisbon Portugal' and Institute of Animal Reproduction and Food Research of PAS, Olsz- \\ tyn, Poland ${ }^{2}$
}

\begin{abstract}
Summary
Cytokines may play a dual role in the reproductive tract - either involved in physiologic processes or mediating inflammation and other pathologic processes. Physiologic secretory and angiogenic function in the equine endometrium appears to be regulated by cytokines TNF $\alpha$, FasL, IFN $\gamma$ through their receptors. These receptors are present in glandular epithelium, and stroma cells and their mRNA expression changes throughout the estrous cycle. Besides, interleukins (IL- $1 \alpha$ and IL-1 $\beta$ ) and their receptors mRNA expression vary according to various degrees of endometrium inflammation (endometritis) and fibrosis (endometrosis). A novel paradigm in innate immunity and neutrophils (PMN) hyperactivation is PMN ability to cast out their DNA in response to infectious stimuli. These PMN extracellular traps (NETs) bind and kill pathogens, at the infection site. The intriguing dilemma is that even though NETs may function as a first line of defense, they also release molecules that may contribute to tissue damage. Thus, we postulate that PMN present in the endometrium at estrus, mating or infection, might form NETs, and release nucleic and cytoplasmic proteins with immunomodulatory properties. Equine PMN stimulated in vitro showed NETs formation capacity when in contact with some bacteria strains obtained from mares with endometritis, such as Streptococcus zooepidemicus, Escherichia coli and Staphylococus capitis. In this regard, even though NETs and cytokines function as an effective antimicrobial first line of defense or modulate physiologic endometrial function, respectively (friends), they may also be involved in endometrial fibrosis pathogenesis and endometrial secretory function impairment, due to enhanced NETs formation and/or a decrease on NETs degradation (foes).
\end{abstract}

Keywords: Neutrophil extracellular traps; cytokines, mare, endometrium, endometritis, reproduction

\section{Zytokine und „neutrophile extrazelluläre Fallen” im Endometrium des Pferdes - Freund oder Feind?}

Zytokine können im Reproduktionstrakt in zweifacher Hinsicht eine Rolle spielen: zum einen sind sie an physiologischen Prozessen beteiligt, zum anderen vermitteln sie bei Entzündungen oder anderen Alterationen. Die equine endometriale physiologische sekretorische und angiogene Funktion scheint durch die Zytokine TNF $\alpha$, FasL, IFN $\gamma$ durch ihre Rezeptoren reguliert zu werden. Diese sind in den glandulären Epithelien und den Stromazellen lokalisiert, ihre mRNA Expression ist innerhalb des Zyklusgeschehens veränderlich. Darüber hinaus variieren die Interleukine (IL- $1 \alpha$ und IL-1 $\beta$ ) und ihre Rezeptor-mRNA-Expression in Abhängigkeit vom Grad der Endometritis und Endometrose (periglanduläre Fibrose). Ein neues Denkmodell bezüglich der angeborenen Immunität und der Hyperaktivität der neutrophilen Granulozyten (PMN) ist die Ausschüttung ihrer DNA als Reaktion auf einen infektiösen Stimulus. Diese neutrophil extracelluar traps - "Neutrophile extrazelluläre Fallen", NETs, binden und töten pathogene Keime, im Falle einer Infektion. Das faszinierende Dilemma dabei ist, dass obwohl NETs ihre Rolle an vorderster Front der Abwehr spielen können, sie ebenfalls Moleküle abgeben, die zum Gewebsschaden beitragen. Daher postulieren wir, dass PMNs im Endometrium zur Zeit des Östrus, der Bedeckung oder Infektion NETs bilden und nukleäre oder zytoplasmatische Proteine mit immunmodulatorischen Fähigkeiten ausschütten. Equine PMN, die in vitro stimuliert worden sind, zeigen die Kapazität zur NETs-Bildung, wenn sie in Kontakt mit Bakterienstämmen kommen, die aus dem Stutenendometrium isoliert wurden, wie Streptococcus zooepidemicus, Escherichia coli und Streptococcus capitis. In dieser Hinsicht ist festzustellen, dass obwohl NETs und Zytokine als Bestandteile einer effektiven antimikrobiellen Abwehr an vorderster Front fungieren bzw. die physiologische endometriale Funktion modulieren (Freunde), sie auch an der Pathogenese der endometrialen Fibrose und gestörten endometrialen sekretorischen Funktion beteiligt sein können, verursacht durch eine gesteigerte NETs Bildung und/oder deren verminderten Abbau (Feinde).

Schlüsselwörter: Neutrophil extracellular traps (NETs), Zytokine, Stute, Endometrium, Endometritis, Reproduktion

\section{Introduction}

The endometrium is a very complex tissue that undergoes physiologic changes throughout the estrous cycle, which are required for establishment and maintenance of pregnancy. In the mare, as in other mammals, endometrium cyclic regulation is mainly driven by the changing pattern of the ovarian steroid hormones estradiol (E2) and progesterone (P4), and endometrial prostaglandins (PG) (Stout and Allen 2002; Roberto da Costa et al. 2007a). Thus, also in the mare, the endometrium undergoes angiogenic changes and cellular proliferation/apoptosis to prepare the uterus for pregnancy (Ferreira-Dias et al. 2001, Roberto da Costa et al. 2007a;
$2007 b, 2008)$. In fact, in the mid luteal phase, cell hyperplasia and increased protein synthesis occur in equine endometrium, at the time the histotroph would be needed for eventual embryo nourishment (Roberto da Costa et al. 2007a).

Considerable evidence supports that cytokines are essential to normal processes such as cell renewal and tissue homeostasis. Even though cytokines have been known to be produced by inflammatory cells, in the reproductive tract also non inflammatory cells, such as stroma and epithelial cells are involved in cytokine production. Therefore, cytokines 
may play a dual role in the reproductive tract - either involved in physiologic processes or mediating inflammation and other pathologic processes.

\section{Cytokines in the endometrium}

The influence of the endometrium in ovarian function regulation has been well established, for decades. Specifically, during the luteal phase, the relationship between these two structures is quite evident, mainly at the time of luteolysis. Even though cytokines in the endometrium of mares were first addressed in pathologic conditions, such as endometritis (Fumuso et al. 2003), lately their role on the physiologic regulation of endometrial secretory and angiogenic function has been studied (Roberto da Costa et al. 2008). Specifically in the mare reproductive tract, cytokines tumor necrosis factor alpha (TNF $\alpha$ ), interferon gamma (IFN $\gamma)$, Fas ligand (FASL), transforming growth factor beta (TGF $\alpha$ ), and interleukins (IL) have been related to luteal secretory capacity (Galvão et al. 2010); endometrial and/or trophoblast growth and differentiation during placentation (Lennard et al. 1995) and endometrial response to semen (Palm et al. 2008). Nevertheless, the specific manner concerning cytokines interaction in the equine endometrium for the establishment of different events during the estrous cycle, is not well known. We have shown by immunohistochemistry that cytokine ligands TNF $\alpha$, FasL, IFN $\gamma$ and their receptors are present in glandular epithelium and stroma cells in the mare endometrium. Also, in early and late luteal phases endometria, TNF $\alpha$ mRNA expression increased $(p \leq 0.05)$, while its receptor showed the opposite tendency ( $p \leq 0.05)$ (Galvão et al. 2008). Even though, FasL expression was similar to TNF $\alpha$, being lower in the mid luteal phase $(p<0.05)$, Fas was constant throughout the luteal phase (Galvão et al. 2008). However, cytokine IFNy mRNA expression was only increased in the late luteal phase $(p<0.05)$, with no change in its receptor (Galvão et al., 2008).

These results suggest an important auto/paracrine role of these cytokines in regulation of endometrial function. In addition, the agreement between the expression pattern of these cytokines and their receptors in both the equine endometrium and the ovary may show similar pathways triggered simultaneously in the luteal phase, in both structures (Galvão et al. 2008). Besides cytokine presence in endometrium stroma and glandular cells in the mare, TNF $\alpha$ has been shown to stimulate endometrial explants to produce PGF $2 \alpha$ in all phases of the estrous cycle $(P<0.05)$, while PGE2 was only increased in early and mid luteal phases (Roberto da Costa et al., 2008). However, in another study, this cytokine and the peptide hormone oxytocin (positive control) stimulated PGE2 by equine endometrial cell culture in the follicular phase in the mid luteal phase, while TNF $\alpha$ only stimulated PGF $2 \alpha$ production in the follicular phase $(p<0.05)($ Fig. 1). Specific features of each system (endometrial explants vs endometrial mixed cell culture) might explain the disagreement between both studies. Possibly, the proportion of both stroma and epithelial cell types in cultures was not the same as in tissue explant culture. In the same study, this cytokine increased endometrial cells viability, nitric oxide (NO) production and angiogenic activity. Therefore, cytokine action coordinated with ovarian steroid hormones appears to be determinant for regulation of secretory, angiogenic and proliferative functions in equine endometrium.

Cytokines have been known as mediators of inflammatory processes in the reproductive tract. In the mare, inflammation of the endometrium (endometritis) is responsible for early embryonic death and infertility. This is mostly associated with post insemination persistent endometritis or chronic degenerative endometritis/endometrosis (Troedsson 1997, LeBlanc 1997). Even though the etiology of endometrosis is not completely understood, this process appears to be triggered by endometritis, severe angiosclerosis, impaired physiologic cell renovation, collagen accumulation resulting in periglandular fibrosis and gland destruction (Hoffmann et al. 2009). Endometritis/endometrosis may also be responsible for failure of

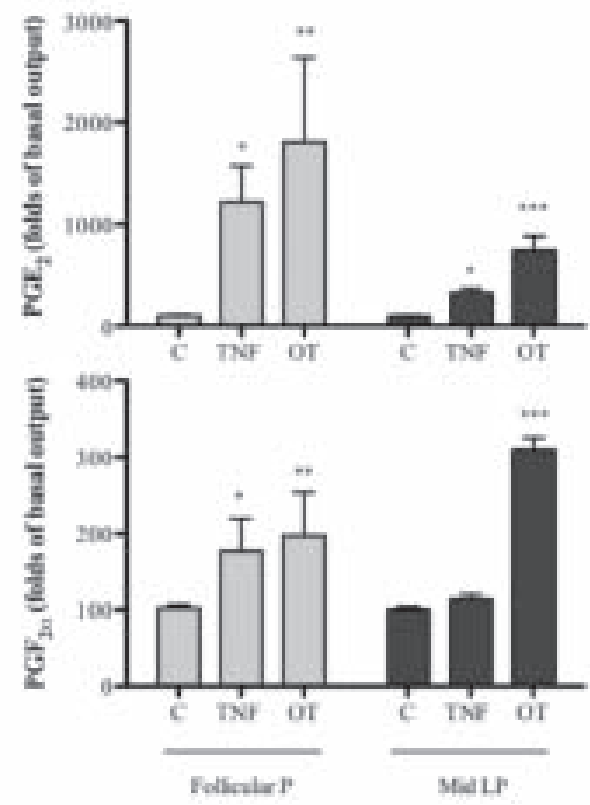

Fig. 1 Effects of TNF $\alpha$ and oxytocin (OT) on PGE2 and PGF2 $\alpha$ production by equine endometrial cells obtained during the follicular (grey bars) and mid luteal phases (black bars). Asterisks indicate significant differences from control $\left({ }^{*} \mathrm{p}<0.05\right.$; ${ }^{* *} \mathrm{p}<0.01$; ${ }^{* * *}$ $\mathrm{p}<0.001)$.

Auswirkung von TNF $\alpha$ und Oxytocin (OT) auf die PGE2- and PGF2 $\alpha$ Produktion durch equine endometriale Zellen, die während der Follikelphase (grave Balken) und in der mittleren Lutealphase (schwarze Balken) gewonnen wurden. Die Sterne zeigen signifikante Differenzen im Vergleich zu den Kontrollen $\left({ }^{*} p<0.05 ;{ }^{* *} p<0.01\right.$; ${ }^{* * *}$ $p<0.001)$.

the physiologic modulatory interaction between cytokines and PG in the endometrium, resulting in embryo death. In fact, inflammation and fibrosis in the equine endometrium appear to be associated with abnormal enzyme activity involved in prostanoids synthesis, such as PGE2 and PGF2 $\alpha$, which seems to be estrous cycle hormone dependent, and could be responsible for early embryo loss (Szóstek et al. 2011 a).

In order to better understand equine endometritis, pro-inflammatory cytokines were studied in the endometrium from mares susceptible to endometritis (Fumuso et al. 2003). This study showed no effect of the estrous cycle on mRNA expression of pro-inflammatory cytokines (interleukin: IL- $1 \alpha$; IL-6 and $T N F \alpha$ ), even though mares resistant to endometritis had 
a lower mRNA cytokine expression than mares susceptible to endometritis (Fumuso et al. 2003). Also, induced delayed uterine clearance in mares had a profound effect on uterine inflammation, with increased IL- 6 and TNF- $\alpha$ accumulation in the uterine fluids (Liepina et al., 2010). In our most recent study on equine endometrium, IL- $1 \alpha$ and IL- $1 \beta$ and their receptors (IL-1RI, IL-1RII) mRNA expression was related to various degrees of inflammation and fibrosis according to Kenney (1978), and estrous cycle phase. Expression of IL- $1 \alpha$ was increased in category || endometrium in the late luteal phase of the estrous cycle, while it was lower in category III in the same phase. In category III endometrium, this interleukin was higher only in mid and late luteal phases $(p<0.05)$. IL- $1 \alpha$ mRNA expression in endometrium was higher in category II endometrium in early and mid luteal phases $(p<0.05)$, while it was decreased in endometrosis (category III) $(p<0.01)$ (Szóstek et al. 2011 b). Also, when category II endometrium was stimulated in vitro by these cytokines, IL-1 $\beta$ increased PGE2 secretion in categories I and I| endometrium, while IL-1 $\beta$ increased PGE2 in categories I and III and PGF2 $\alpha$ secretion only in category III endometrium (Szóstek et al. 2011 b). Thus, since inflammation is predominant in endometrium category II, while fibrosis prevails in category III, it appears that IL- $1 \alpha$ and IL- $1 \beta$ that are expressed differently in mare endometrium with different degrees of fibrosis and/or inflammation, might be estrous cycle hormone dependent and be involved in PG synthesis, modulating not only endometrial physiologic function but also uterine pathology.

\section{Neutrophil extracellular traps}

Endometrial pathology has been associated with impaired early embryonic development and implantation, which results ultimately in pregnancy loss. Equine endometrits, is caused by a small variety of bacteria such as Escherichia coli, Pseudomonas aeruginosa, Klebsiella sp., Proteus, Corynebacterium, being Streptococcus equi subespecies zooepidemicus the most common agent (Wittenbrink et al. 2008). However, it is not clear which stimuli are the most important ones for the induction of endometritis/endometrosis and which components modulate the inflammatory response in the uterus. Many facts of the pathophysiology of neutrophil (PMN) hyperactivation and its role in severe inflammatory disorders are largely unknown. A novel paradigm in innate immunity has been recently described as PMN casting out their DNA in response to infectious stimuli (Brinkmann et al. 2004). These PMN extracellular traps (NETs) have the ability to bind and kill pathogens, at the site of infection. Recently, this active process was called NETosis and unlike apoptosis and necrosis, it involves antimicrobial and proinflammatory responses (Fuchs et al. 2007). NETs are large DNA-associated molecule complexes carrying nucleic and cytoplasmic proteins, each with strong antimicrobial and/or immunomodulating properties (Lögters et al. 2009).

The intriguing dilemma is that even though NETs may function as a first line of defense, they also release molecules that may contribute to collateral damage within inflamed tissues (Lögters et al. 2009). This may lead to cell matrix and connective tissue destruction, vasculitis, fibrosis and organ failure like in human cystic fibrotic lung (Marcos et al. 2010). In that context, the mare endometrium has the unique capacity to develop sub-epithelial and periglandular fibrosis (collagen) in response to non-infectious and infectious stimuli. This pathology renders the uterus incapable of adequate endometrial function, crucial for embryo survival, leading to early pregnancy loss. In spite of extensive research on endometritis/endometrosis the mechanism for endometrial fibrosis, remains an unsolved mystery. Thus, we postulate that PMN present in the endometrium at estrus, mating or infection, might form NETs, and release nucleic and cytoplasmic proteins with immunomodulatory properties. In fact, equine spermatozoa in utero led to NETs formation (Alghamdi et al. 2009). Besides, our preliminary studies show that in vitro stimulated equine PMN have NETs formation capacity when in contact with some bacteria strains obtained from mare endometritis (Rebordão et al. 2011 ) (Fig. 2).

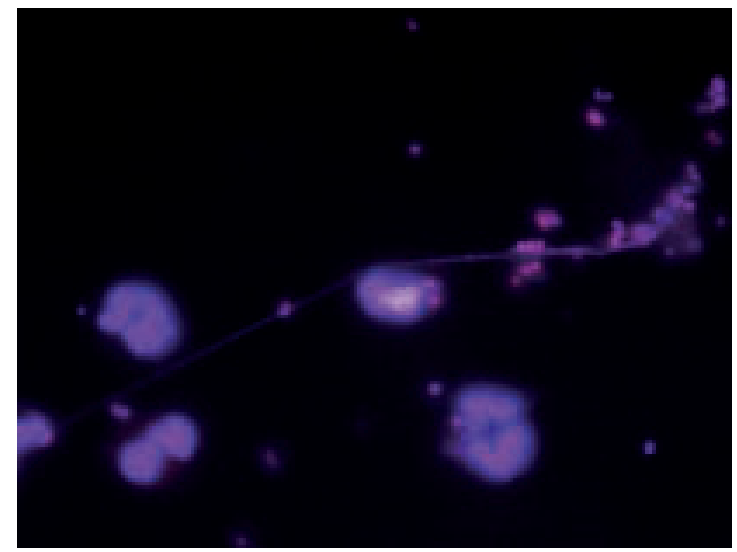

Fig. 2 Equine PMN extracellular trap (NET) formed in the presence of Staphylococcus capitis and $10 \mathrm{ug} / \mathrm{ml}$ Cytochalasin C, stained with DAPI and observed under fluorescence microscope (100x). Equine NETs ("neutrophile extrazelluläre Fallen"), die in Anwesenheit von Staphylococcus capitis und $10 \mathrm{ug} / \mathrm{ml}$ Cytochalasin $C$ gebildet wurden. (DAPI-Färbung, Fluoreszenzmikroskopie, 100x)

These novel findings suggest that NETs formation might be a mechanism to fight some bacteria endometritis, but also to develop endometrium fibrosis. Besides, fibrosis appears to be regulated by a number of interacting factors including an extremely complex network of profibrotic cytokines (Cadario et al. 2002). It is intriguing that numerous bacteria, such as Streptococcus pneumonia, have evolved the ability to produce DNases, which increases their virulence (Brinkmann et al. 2004). This might explain why, in our in vitro preliminary studies, Streptococcus zooepidemicus when in contact with stimulated equine PMN showed a lower NETs formation ability than other bacteria. However, Staphylococcus capitis (Fig 2) was able to stimulate a higher number of NETs from equine PMN. Thus, understanding these dissimilarities among endometritis pathogens, on their NETs production ability and on their effects on endometrium cells/fibroblasts, might explain their role on endometritis and/or fibrosis deposition. Only by understanding the intricacies, at gene and molecular levels, of the pathophysiologic mechanisms of endometrial fibrosis, this pathology can be fought. In this regard, even though NETs and cytokines function as an effective antimicrobial first line of defense or modulate physiologic endometrial function, respectively (friends), they may also be involved in endometrial fibrosis pathogenesis and endometrial secretory function impairment, due to enhanced NETs formation and/or a decrease on NETs degradation (foes). 


\section{Grant support}

This study was supported by Grants of MS\&HE: DPN N5/COST/2010; CIISA 75/Angiogénese-Apoptose (Portugal); and PTDC/CVT/121805/2010 (Fundação para a Ciência e Tecnologia - FCT, Portugal). AZS was supported by the European Union within the European Social Fund; MMR and AG were supported by Doctoral grants from FCT, Portugal (SFRH/PROTEC/50213/2009; SFRH/BD/ 29765/2006).

\section{References}

Alghamdi A. S., Lovaas B. J., Bird S. L., Lamb G. C., Rendahld A. K., Taube P. C. and Foster D. N. (2009) Species-specific interaction of seminal plasma on sperm-neutrophil binding. Anim. Reprod. Sci. $114,331-344$

Bradley J. R. (2008). TNF-mediated inflammatory disease. J. Pathol. $214,149-160$

Brinkmann V., Reichard U., Goosmann C., Fauler B., Uhlemann Y., Weiss D. S., Weinrauch Y. and Zychlinsky A. (2004) Neutrophil extracellular traps kill bacteria. Science 303,1532-1535

Cadario M. E., Losinno L., Giguere S., Aguilar J., Jack T. J., Macpherson M. L., Fitzpatrick C. and Uhl E. W. (2002) Uterine expression of fibrogenic cytokines in the mare. Theriogenology. 58, 449-452

Ferreira-Dias G., Serrão P. M., Costa Durão J. and Robalo Silva J. (2001) Microvascular development and growth of the uterus during the estrous cycle in the mare. Am. J. Vet. Res. 62,526-530

Fuchs T. A., Abed U., Goosmann C., Hurwitz R., Schulze I., Wahn V., Weinrauch Y., Brinkmann V. and Zychlinsky A. (2007) Novel cell death program leads to neutrophil extracellular traps. J. Cell Biol. 176,231-241

Fumuso E., Giguère S., Wade J., Rogan D., Videla-Dorna I. and Bowden R. A. ( 2003) Endometrial IL-1b, IL-6 and TNF- $\alpha$, mRNA expression in mares resistant or susceptible to post-breeding endometritis Effects of estrous cycle, artificial insemination and immunomodulation. Vet. Immunol. Immunopathol. 96,31-41

Galvão A., Skarzynski D., Silva. E., Valente L., Mateus L., Korzekwa A. and Ferreira-Dias G. (2008) Cytokines in the mare endometrium and corpus luteum. Jubileuszowy Zjazd Towarzystwa Biologii Rozrodu, 10-13 September, Wroclaw, Poland. Pp: 107-108

Galvão A., Ramilo D., Skarzynski D., Lukasik K., Tramontano A., Mollo A., Mateus L. and Ferreira-Dias G. (2010) Is Fas/Fas Ligand System Involved In Corpus Luteum Functional Regression? Biol. of Reprod. 83,901-908

Hoffmann C., Ellenberger C., Costa Mattos R., Aupperle H., Dhein S., Stief B. and Schoon H-A. (2009) The equine endometrosis: New insights into the pathogenesis. Ani. Reprod. Sci. 111, 261278

Kenney R. M. (1978) Cyclic and pathological changes of the mare endometrium as detected by biopsy, with a note on embryonic death. J. Am. Vet. Med. Assoc. 172, 241-262

LeBlanc M. M. (1997) Clinical aspects of endometritis. Pferdeheilkunde 13, 538

Lennard S. N., Stewart F. and Allen W. R. (1995) Transforming growth factor $\beta 1$ expression in the endometrium of the mare during placentation. Molecular Reproduction and Development. 42,131-140

Liepina E., Rivera del Alamo M. M., Reilas T. and Katila T. (2010) IL6 and TNF- $\alpha$ expression in uterine fluids of mares with induced delay in uterine clearance. Animal Reproduction Science. 121, 12, suppl. 1, 107-108

Lögters T., Margraf S., Altrichter J., Cinatl J., Mitzner S., Windolf J. and Scholz M. (2009) The clinical value of neutrophil extracellular traps. Med. Microbiol. Immunol. 198,211-219
Marcos V., Zhou Z., Yildirim A.Ö., Bohla A., Hector A., Vitkov L., Wiedenbaver E-M., Krautgartner W. D., Stoiber W., Belohradsky B. H., Rieber N., Kormann M., Koller B., Roscher A., Roos D., Griese M., Eickelberg O., Döring G., Mall M. A. and Hartl D. (2010) CXCR2 mediates NADPH oxidase-independent neutrophil extracellular trap formation in cystic fibrosis airway inflammation. Nature Medicine 16,1018-1024

Palm F., Walter I., Budik S., Kolodziejek J., Nowotny N. and Aurich C. (2008) Influence of different semen extenders and seminal plasma on PMN migration and on expression of IL- $1 \alpha, I L-6$, TNF- $\alpha$ and COX-2 mRNA in the equine endometrium. Theriogenology 70, 843-851

Rebordão M. R., Serrão P. M., Carneiro C., Leitão A., Vilela C. and Ferreira-Dias $G$. (2011) Equine endometritis bacteria and neutrophil extracellular traps. 15th Conference of European society for Domestic Animal Reproduction, 15-17 September, Antalya, Turkey, in press.

Roberto da Costa R. P., Serrão P. M, Monteiro S., Pessa P. and Ferreira-Dias G. (2007a) Caspase-3 mediated apoptosis and cell proliferation in the equine endometrium during the oestrous cycle. Reprod. Fertil. Develop. 19, 925-932

Roberto da Costa R. P., Ferreira-Dias G., Mateus L., Korzekwa A., Andronowska A., Platek R. and Skarzynski D. J. (2007b). Endometrial nitric oxide production and nitric oxide synthases in the equine endometrium: relationship with microvascular density during the estrous cycle. Domest. Anim. Endocrinol. 32, 287-302

Roberto da Costa R. P., Costa A. S., Korzekwa A., Platek R., Siemieniuch M., Galvão A., Redmer D. A., Robalo Silva J., Skarzynski D. J. and Ferreira-Dias G. (2008) Actions of a nitric oxide donor on prostaglandins production and angiogenic activity in the equine endometrium. Reprod. Fertil. Develop. 20, 674-683.

Stout T. A. and Allen W. R. (2002) Prostaglandin E(2) and $F(2 \alpha)$ production by equine conceptuses and concentrations in conceptus fluids and uterine flushings recovered from early pregnant and dioestrous mares. Reproduction 123, 261-268

Szóstek A. Z., Galvão A. M., Majewska M., Siemieniuch M., Krzywiec W., Ferreira-Dias G. and Skarzynski D. J. (2011a) Prostaglandin (PTG) synthases mRNA expression in the equine endometrium: fibrosis and estrous cycle dependence. 44th Annual Meeting of the Society for the Study of Reproduction, 31 July-4 Aug 2011, Portland, Oregon, USA. In press

Szóstek A. Z., Rebordão M. R., Kolomycka A., Galvão A., FerreiraDias G. and Skarzynski D. J. (2011b). Fibrosis and Interleukin-1 and expression in the equine endometrium and neutrophil extracellular traps formation. Polish-Japanese Joint Symposium, 1315th September, Morioka, Iwate, Japan. In press

Troedsson M. H. T. (1997) Therapeutic consideratins for matinginduced endometritis. Pferdeheilkunde 13,516-520

Wittenbrink M. M., Hoelzle K. and Hoelzle L. E. (2008) What's new in bacteriology of the mare's genital tract. Pferdeheilkunde 24, 53-55

Prof. Graça Ferreira-Dias

Faculdade de Medicina Veterinária

Av. Universidade Técnica

1300-477 Lisboa

Portugal

gmlfdias@fmv.utl.pt 